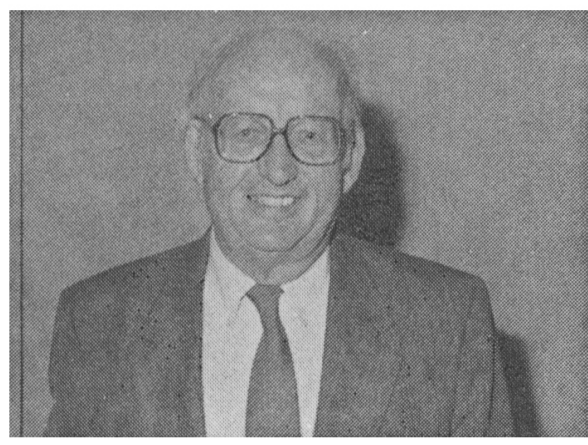

ROBERT C. WOOD

Section's Herbert Kaufman Award for the best paper in public administration presented at the previous year's Annual Meeting. Doig was recognized for his 1988 paper," "Entrepreneurship in Government."

The first George Hallett Prize of the Representation and Electoral Systems Section was presented by Bernard Grofman, of the University of California, Irvine, to Douglas Rae of Yale University. The Hallett Prize for a book published at least ten years ago that has made a lasting impression in the understanding of representation and electoral systems recognized Rae's The Political Consequences of Electoral Laws (Yale University Press, 1967; 2nd revised edition, (97I).

\section{Urban Politics Section Awards, 1989}

The APSA Organized Section on Urban Politics and Policy presented the following awards at the 1989 Annual Meeting in Atlanta, Georgia:

Robet C. Wood, Henry Luce Professor of Democratic Institutions and the Social Order, Wesleyan University, the 1989 Career Achievement Award for distinguished scholarship in the field of urban politics.

Charles V. Hamilton, Wallace S. Sayre Professor of Government, Columbia University, Special Award for scholarly con- tributions to understanding the racial problems and politics in American cities.

Steven P. Erie, University of California, San Diego, Best Book in Urban Politics in 1988, for his book Rainbow's End: Irish Americans and the Dilemmas of Urban Mochine Politics, 1840-1985. Erie's book also was awarded the 1989 Robert Park Award given by the American Sociological Association.

Lawrence A. Cremin, Columbia University, 1988 Special Citation for his book American Education, The Metropolitan Experience, 1876-1980.

James $C$. Clingermayer, Texas A\&M University, for the best dissertation completed in 1988. His dissertation, submitted by Washington University, St. Louis, is entitled, "The Political Economy of Municipal Zoning." The Section's dissertation award is sponsored by the Urban Affairs Quarterly and the journal of Urban Affairs.

\section{Richard F. Fenno, Jr. Prize for 1989 Announced; Award Committee for 1990 Set}

The Legislative Studies Section of the American Political Science Association announced the 1989 winner of the Richard F. Fenno, Jr. Prize at the LSS Awards Ceremony held in Atlanta at the APSA Annual Meeting. The Fenno Prize honors the outstanding book published during the preceding year in legislative studies, including American, non-American, cross-national, and sub-national works.

The 1989 Fenno Prize was conferred upon David Brady of Stanford University for his book Critical Elections and Congressional Policy-Making, published in 1988 by Stanford University Press. The LSS Committee that decided upon the Fenno Prize was chaired by Morris Fiorina of Harvard University. Other members of the Fenno Committee were Gerhard Loewenberg of 